\title{
The Utilization of Bacillus megaterium and the Release of a Lytic Enzyme by Three Epidinium spp. Isolated from the Rumen
}

\author{
By G. S. COLEMAN AND JUDITH I. LAURIE \\ Agricultural Research Council Institute of Animal Physiology, Babraham, \\ Cambridge CB2 $4 A T$
}

(Received 9 April 1974; revised 26 July 1974)

\begin{abstract}
SUMMARY
Washed suspensions of three Epidinium spp., grown in vitro and incubated anaerobically in salts solution, released into the medium protein containing hexokinase and an enzyme which lysed Bacillus megaterium, B. subtilis and Micrococcus lysodeikticus. Material from the lysate, containing bound amino acids, was incorporated by Epidinium spp. at a rate that would allow only very slow growth if it were the sole source of nitrogen. Although there was no massive cell lysis the enzymes were liberated as the result of a release of whole cell contents by an unknown mechanism. In the presence of other rumen protozoa, protein, but no lytic enzyme, appeared in the medium. No good evidence was obtained for the existence in the rumen of a lytic enzyme associated with the presence of Epidinium spp.
\end{abstract}

\section{INTRODUCTION}

Bacterial species can be divided into two groups on the basis of the rate at which soluble material appears in the medium on incubation with an Epidinium sp. With most Grampositive and all Gram-negative bacteria tested (Coleman \& Laurie, 1974) no soluble material was released although the bacteria were engulfed by the protozoa, whereas with Bacillus megaterium, B. subtilis and Micrococcus lysodeikticus 20 to 40 times as many bacteria were digested in $30 \mathrm{~min}$ as were found inside the protozoa at that time. This paper shows that the protozoa released into the medium protein and at least two enzymes, one of which lysed the above bacteria. The lytic products were then incorporated by the Epidinium. A preliminary communication describing some of this work has already appeared (Coleman, I973).

\section{METHODS}

The three isolates of Epidinium ecaudatum caudatum described by Coleman \& Laurie (1974) were used and all gave similar results. Bacillus megaterium KM was grown as described for Escherichia coli by Coleman (1967) and washed suspensions were prepared in salt solution D (Coleman, 1972). Protein was estimated by the method of Lowry, Rosebrough, Farr \& Randall (I95I) and precipitated by zinc and barium (Somogyi, 1945). Hexokinase was estimated by the method of Coleman (1969). Lytic enzymes were assayed in $\mathrm{I} \cdot 0 \mathrm{ml}$ salt soln D containing about $50 \times 10^{6} \mathrm{U}-{ }^{14} \mathrm{C}$-labelled Bacillus megaterium (approx. 5000 c.p.m.) and o to $0.3 \mathrm{ml}$ enzyme preparation, in tubes incubated at $39^{\circ} \mathrm{C}$. After $0,10,20,30$ or $40 \mathrm{~min}$, tubes were centrifuged at $4000 \mathrm{~g}$ for $15 \mathrm{~min}$ and ${ }^{14} \mathrm{C}$ in $0.2 \mathrm{ml}$ of the supernatant was estimated. The maximum amount of ${ }^{14} \mathrm{C}$ solubilized was $45 \%$ and results in which more than $30 \%$ was released were discarded. All other methods have been described by Coleman (I958, 1972). 


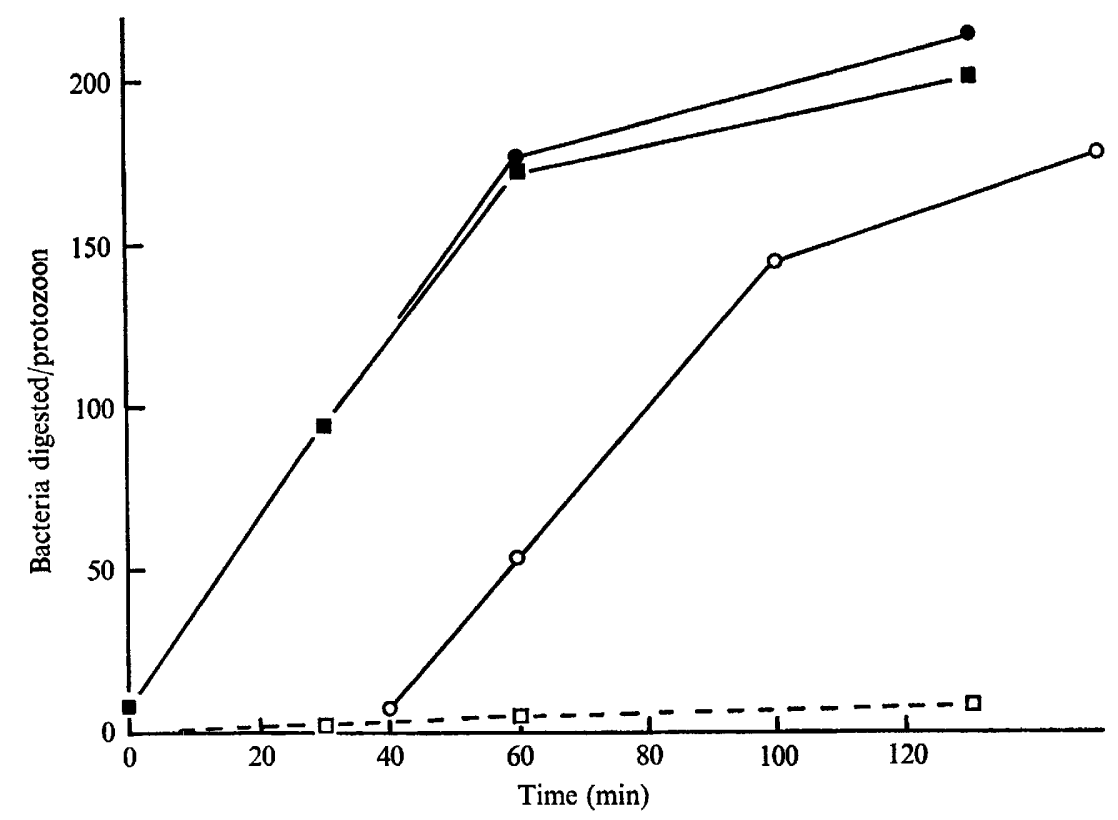

Fig. I. Rate of liberation of soluble ${ }^{14} \mathrm{C}$ into the medium from $10^{8} \mathrm{U}-{ }^{14} \mathrm{C}$-labelled B. megaterium/ $\mathrm{ml}$ in the presence of Epi. ecaudatum caudatum (ovine). - E - Epidinium present throughout; - - Epidinium removed at $30 \mathrm{~min} ; \mathrm{O}-\mathrm{O}$, Epidinium incubated for $30 \mathrm{~min}$ in the absence of bacteria and then the supernatant fluid incubated with bacteria; $\square---\square,{ }^{14} \mathrm{C}$ incorporated by the protozoa in the presence of bacteria. The results have been corrected for the liberation of ${ }^{14} \mathrm{C}$ without added protozoal preparation (approx. equal to 20 bacteria/protozoon at $130 \mathrm{~min}$ ).

\section{RESULTS}

The metabolism of Bacillus megaterium by Epidinium spp.

On incubation of washed suspensions of $\mathrm{U}^{14} \mathrm{C}$-labelled B. megaterium with Epi. ecaudatum caudatum (ovine or bovine) or Epi. ecaudatum tricaudatum, there was a rapid appearance of soluble ${ }^{14} \mathrm{C}$-labelled material in the medium without appreciable engulfment of bacteria by the protozoa (Fig. I). In one experiment with Epi. ecaudatum caudatum (ovine), the numbers of bacteria digested to bacteria inside each protozoon were $25,33,35,88$ and 62 (after correction for lysis of bacteria in the absence of protozoa) at 5, I5, 30, 60 and 120 min respectively. If digestion occurred only after engulfment of the bacteria by the protozoon, then, at the first three time points, each bacterium must have been engulfed, killed and digested in less than $\mathrm{I}$ min. This very short period, compared with 30 to $60 \mathrm{~min}$ found with Entodinium caudatum and Ento. simplex (Coleman, 1964, 1972), indicates that lysis was occurring without engulfment, possibly by the action of a lytic enzyme released by the protozoa. To test this possibility, liberation of ${ }^{14} \mathrm{C}$ from ${ }^{14} \mathrm{C}$-labelled $B$. megaterium was measured: with protozoa and bacteria together throughout the experiment; under the same conditions except that the protozoa were removed by centrifuging after $30 \mathrm{~min}$; and by incubation of the bacteria with the supernatant fluid obtained by incubating Epidinium in salts solution for $30 \mathrm{~min}$. Removal of the protozoa after $30 \mathrm{~min}$ had no effect on the rate of digestion of the bacteria and, in the presence of the protozoal incubation medium, digestion proceeded as rapidly as in the presence of the protozoa (Fig. I). This suggests the action of an extracellular enzyme and that the digestion of engulfed bacteria was quantitatively unimportant. The rate of lysis of 
Table I. The release of protein from and the digestion of B. megaterium by three species of Epidinium and Polyplastron multivesiculatum

\begin{abstract}
Epidinium ecaudatum caudatum (ovine) (29000), Epi. ecaudatum caudatum (bovine) (I4000), Epi. ecaudatum tricaudatum (10000) and Polyplastron multivesiculatum ( 740 grown without Epidinium) were incubated anaerobically with or without $75 \times 10^{6} \mathrm{U}-{ }^{14} \mathrm{C}$-labelled $B$. megaterium $/ \mathrm{ml}$. The amounts of protein in the supernatant fluid and the protozoal broken-cell supernatant fluid were determined and the number of bacteria digested calculated from the ${ }^{14} \mathrm{C}$ in supernatant fluid and the specific activity of the bacteria added initially. The results are all expressed per protozoon.
\end{abstract}

\begin{tabular}{|c|c|c|c|c|c|c|c|c|}
\hline \multirow[b]{2}{*}{$\begin{array}{r}\text { Time } \\
(\min )\end{array}$} & \multicolumn{2}{|c|}{$\begin{array}{c}\text { Epi. ecaudatum } \\
\text { caudatum } \\
\text { (ovine) }\end{array}$} & \multicolumn{2}{|c|}{$\begin{array}{c}\text { Epi. ecaudatum } \\
\text { caudatum } \\
\text { (bovine) }\end{array}$} & \multicolumn{2}{|c|}{$\begin{array}{c}\text { Epi. ecaudatum } \\
\text { tricaudatum }\end{array}$} & \multicolumn{2}{|c|}{$\begin{array}{c}\text { Polyplastron } \\
\text { multivesiculatum }\end{array}$} \\
\hline & $\begin{array}{l}\text { Protein } \\
\text { (ng) }\end{array}$ & $\begin{array}{l}\text { Bacteria } \\
\text { digested }\end{array}$ & $\begin{array}{l}\text { Protein } \\
\text { (ng) }\end{array}$ & $\begin{array}{l}\text { Bacteria } \\
\text { digested }\end{array}$ & $\begin{array}{l}\text { Protein } \\
\text { (ng) }\end{array}$ & $\begin{array}{l}\text { Bacteria } \\
\text { digested }\end{array}$ & $\begin{array}{l}\text { Protein } \\
\text { (ng) }\end{array}$ & $\begin{array}{l}\text { Bacteria } \\
\text { digested }\end{array}$ \\
\hline \multicolumn{9}{|c|}{ Protozoal broken-cell supernatant fluid } \\
\hline 0 & $2 \mathrm{I} \cdot 2$ & & 24.5 & & $15 \cdot 2$ & & 9I & \\
\hline \multicolumn{9}{|c|}{ Supernatant fluid in absence of bacteria } \\
\hline 0 & 0.14 & & $0.3 \mathrm{I}$ & & 0.06 & & $2 \cdot 18$ & \\
\hline 60 & 0.59 & & $I \cdot 65$ & & 0.48 & & $5 \cdot 17$ & \\
\hline 200 & I. 04 & & $2 \cdot 45$ & & $\mathbf{I} \cdot 33$ & & $6 \cdot 67$ & \\
\hline \multicolumn{9}{|c|}{ Supernatant fluid in presence of bacteria } \\
\hline 0 & 0.13 & 0 & 0.08 & 0 & 0.0 & 0 & $0 \cdot 0$ & 0 \\
\hline 60 & $\mathrm{I} \cdot 30$ & 1700 & $3 \cdot 30$ & 1790 & $\mathrm{I} \cdot 65$ & 1330 & $3 \cdot 95$ & 0 \\
\hline 200 & I. 43 & 2400 & $3 \cdot 60$ & 2950 & 3.40 & 2950 & $7 \cdot 75$ & 0 \\
\hline
\end{tabular}

bacteria in the medium depended on the age of the bacterial culture, and varied from zero with bacteria in the stationary phase of growth, to $13.3 \times 10^{3}$ bacteria/protozoon during a I00 min incubation with bacteria in the exponential growth phase. Similar experiments were made with Ento. caudatum (grown as described by Coleman, 1960), Polyplastron multivesiculatum (grown in the presence or absence of an Epidinium sp. as described by Coleman, Davies \& Cash, 1972) and an Ophryoscolex sp. (grown as described for Epidinium spp. by Coleman et al. 1972); no evidence was found for such an enzyme in the incubation media.

The lytic enzyme found in the medium after incubation of the Epidinium spp. could arise by lysis of some of the protozoa, or the specific release of one or more enzymes. These two possibilities were not resolved by counting the number of intact protozoa present because of the inaccuracy of the method and the difficulty of distinguishing live protozoa from those that had just died. It was therefore necessary to compare the amount of enzyme with the amount of protein released.

When the three Epidinium spp. and Polyplastron multivesiculatum (grown in the absence of Epidinium) were incubated without bacteria, 5 to $10 \%$ of the soluble protein in the cell was released progressively into the medium in $200 \mathrm{~min}$ (Table I). In this experiment the rate of release decreased with time, whereas in others it was linear with time for at least $6 \mathrm{~h}$. Similar results were obtained with Polyplastron multivesiculatum grown in the presence of Epidinium, Ophryoscolex or Ento. caudatum. The rate of release of protein was always greatest with Epi. ecaudatum caudatum (bovine): the reason for this is not known. All the protozoal species mentioned had lytic enzyme activity in the broken-cell supernatant fluid, the activities ranging from 3 to $30 \mathrm{bacteria/min} / \mathrm{ng}$ protein; that from Polyplastron multivesiculatum had the same activity as that from Epi. ecaudatum tricaudatum. However, Bacillus megaterium was lysed rapidly only in the presence of Epidinium and the soluble 


\section{Table 2. The release of lytic enzyme, hexokinase and protein during the} incubation of Epi. ecaudatum caudatum

Epidinium ecaudatum caudatum $\left(1.03 \times 10^{5}\right.$ ovine form $\left./ \mathrm{ml}\right)$ were incubated anaerobically in salt soln $D$ for $16 \mathrm{~h}$. At the beginning and end of the incubation $2 \mathrm{ml}$ samples were taken, the protozoa harvested and the cell-free medium and protozoal broken-cell supernatant fluid fractions prepared. The amount of protein was the difference between the values obtained by the method of Lowry et al. (195I) before and after precipitation with $\mathrm{Ba}(\mathrm{OH})_{2}$ and $\mathrm{ZnSO}_{4}$. The lytic enzyme and hexokinase activities are expressed in arbitrary units. The results are expressed per protozoon.

\begin{tabular}{|c|c|c|c|c|}
\hline & Protein & $\begin{array}{c}\text { Non-protein } \\
\text { Lowry-positive } \\
\text { material }\end{array}$ & Lytic enzyme & Hexokinase \\
\hline \multicolumn{5}{|l|}{ Protozoal broken-cell supernatant fluid } \\
\hline Initial & $14.6 \mathrm{ng}$ & 0 & 12600 & $2 \cdot 9$ \\
\hline $\mathrm{I} 6 \mathrm{~h}$ & IO.I ng & 0 & 8000 & $2 \cdot 1$ \\
\hline Loss from protozoa & $31 \%$ & & $37 \%$ & $28 \%$ \\
\hline \multicolumn{5}{|l|}{ Medium } \\
\hline Initial & $0.10 \mathrm{ng}$ & 0 & 0 & 0 \\
\hline $\mathrm{I} 6 \mathrm{~h}$ & $\mathrm{I} \cdot 34 \mathrm{ng}$ & $\mathrm{I} \cdot 93 \mathrm{ng}$ & I 350 & 0.35 \\
\hline $\begin{array}{l}\text { Amount released compared with } \\
\text { that initially present in protozoa }\end{array}$ & $9 \%$ & $\begin{array}{c}13 \% \\
\text { (of initial protein) }\end{array}$ & $11 \%$ & $12 \%$ \\
\hline
\end{tabular}

protein present in the medium increased by 40 to $60 \%$ of that found in the absence of added bacteria. No increase in soluble protein was found on adding $B$. megaterium to suspensions of the other protozoa. In another experiment in which the amounts of lytic enzyme and protein were assayed in the medium and the broken-cell supernatant fluid of Epi. ecaudatum caudatum (ovine) at the beginning and end of an incubation, $7 \cdot 4 \%$ of the soluble protein and $6.3 \%$ of the enzyme activity were released from the protozoa in $4 \mathrm{~h}$, suggesting that all the soluble proteins were being released at the same rate. In addition, material giving a positive reaction in the protein estimation equivalent to $\mathrm{I} \%$ of the soluble protein in the cell was released in a form not precipitable by $\mathrm{Ba}(\mathrm{OH})_{2}$ and $\mathrm{ZnSO}_{4}$.

The protein and the enzyme might have been released from the cell via the anus and be the contents of old food vacuoles. Such protein would not have the same composition as that obtained in general cell lysis. The experiments were therefore repeated using as marker a non-hydrolytic enzyme, hexokinase, which was less likely to be found in the lumen of a food vacuole. To have sufficient enzyme in the medium to assay, the protozoa were incubated for I6 h.

Unfortunately in these longer experiments there was more extensive degradation of the protein released by the protozoa as judged by the effect of $\mathrm{Ba}(\mathrm{OH})_{2}$ and $\mathrm{ZnSO}_{4}$ on the medium. In $\mathrm{I} 6 \mathrm{~h}$ approximately $30 \%$ of the soluble protein and enzymes were lost from the protozoa, confirming that there was general release of cell contents during incubation. (Table 2). Only 30 to $40 \%$ of the protein and enzymes lost by the protozoa was found in the medium, the remainder having been degraded.

The uptake of digested $B$. megaterium. The source of the lytic enzyme was either the protozoal broken-cell supernatant fluid, or the medium obtained after incubation of 210000 Epi. ecaudatum caudatum (ovine) in $4 \mathrm{ml}$ salt soln D for $7 \mathrm{~h}$. These enzyme preparations were incubated with $10^{10} \mathrm{U}-{ }^{14} \mathrm{C}$-labelled $B$. megaterium until the medium cleared (I h with the intracellular and $\mathrm{I} 6 \mathrm{~h}$ with the extracellular enzyme preparation). The solutions were then centrifuged at $5000 \mathrm{~g}$ for $20 \mathrm{~min}$, the supernatant fluids removed and the pellets 
washed once before resuspension in the original volume of salt solution. With both enzyme preparations approximately $77 \%$ of the ${ }^{14} \mathrm{C}$ appeared in the supernatant fluid. Two-dimensional chromatography of this fraction in solvents A and D (Coleman, 1969) revealed over $97 \%$ of the ${ }^{14} \mathrm{C}$ in one spot very close to the origin. Apart from a little ${ }^{14} \mathrm{C}$ in the area where free leucine, isoleucine and phenylalanine appear there was no evidence of any free amino acid. However, after hydrolysis of this supernatant fluid or the residual pellet fraction for $16 \mathrm{~h}$ in $6 \mathrm{~N}-\mathrm{HCl}$ at $105{ }^{\circ} \mathrm{C}$, chromatography of the hydrolysates in solvents $\mathrm{A}$ and $\mathrm{D}$ yielded a complete range of amino acids including diaminopimelic acid.

Both fractions were incubated with a fresh suspension of Epi. ecaudatum caudatum (ovine), ${ }^{14} \mathrm{C}$ uptake measured and the amount of material incorporated calculated in terms of the original bacteria and protein. There was a progressive uptake of ${ }^{14} \mathrm{C}$ from the supernatant fluid fraction by all species of protozoa tested and uptakes were obtained in $5 \mathrm{~h}$ from a solution containing the equivalent of $59 \times 10^{6}$ bacteria $/ \mathrm{ml}$ of (in bacterial equivalents/ protozoon): 570 with Epi.ecaudatum caudatum (ovine), 270 with Epi. ecaudatum tricaudatum, 3260 with Polyplastron multivesiculatum, I580 with an Ophryoscolex sp. and 3 with Ento. caudatum. There was also uptake of ${ }^{14} \mathrm{C}$ from the pellet fraction by Epi. ecaudatum caudatum (ovine) for $3 \mathrm{~h}$ but no soluble ${ }^{14} \mathrm{C}$ was released into the medium. Of the material taken up from the supernatant fluid or pellet fractions, 66 and $4 \mathrm{I} \%$, respectively, were found in the protozoal broken-cell supernatant fluid fraction and of this, 74 and $40 \%$, respectively, were present in the protein fractions. Similar results were obtained for incorporation into the protein of the broken-cell pellet. Two-dimensional chromatography of complete acid hydrolysates of all protein fractions revealed all amino acids to contain ${ }^{14} \mathrm{C}$. Although the ${ }^{14} \mathrm{C}$ in the broken-cell pellet fraction of protozoa incubated with the pellet fraction obtained after digestion with the lytic enzyme could be undigested substrate, the presence of ${ }^{14} \mathrm{C}$ in the broken-cell supernatant fluid fraction from both substrates is taken as evidence that they can be utilized as a source of protein. In a subsequent paper (Coleman \& Hall, 1974) autoradiographic evidence is presented of the sites of incorporation of material from lysed B. megaterium.

The effect of concentration of the soluble and pellet fractions was calculated both in terms of the number of intact bacteria from which the fraction was derived and on the basis of protein mass (Table 3 ). Although the pellet fraction was taken up more rapidly on the first basis, there was much less difference on the basis of protein taken up at a concn of $\mathrm{I} \mathrm{mg} / \mathrm{ml}$. If the soluble fraction at $\mathrm{I} \mathrm{mg} / \mathrm{ml}$ were the sole source of nitrogen then 0.087 times the proportion of ${ }^{14} \mathrm{C}$ taken up that was found in the protein of the broken-cell supernatant fluid, i.e. $0.087 \times 0.66 \times 0.74=0.043 \mathrm{ng}$ protein $/ \mathrm{h}$, would be incorporated into the protozoal broken-cell supernatant fluid. As each Epi. ecaudatum caudatum (ovine) organism contained 12. $6 \mathrm{ng}$ protein in the broken-cell supernatant fluid, it would require $12.6 / 0.043=393 \mathrm{~h}$ for a protozoon to incorporate sufficient material to divide once. Similarly $0.015 \mathrm{ng}$ protein $/ \mathrm{h}$ would be taken up from the pellet fraction into the protein of the broken-cell supernatant fluid to give a division time of $830 \mathrm{~h}$. If both fractions were taken up at the same time the division time would be $214 \mathrm{~h}$. This compares unfavourably with a mean generation time of I I d days in vitro (Coleman et al. 1972) and shows that even in the presence of B. megaterium, the products of the action of the lytic enzyme are unimportant as a source of protein.

Catabolism of bacterial amino acids. There was extensive liberation of non-volatile material into the medium from ${ }^{14} \mathrm{C}$-labelled bacteria and, depending on the amino acid, up to 2.5 times as much material was catabolized to $\mathrm{CO}_{2}$ and volatile fatty acids as was assimilated by the protozoa (Table 4 ).

Lysis of B. megaterium by rumen contents. Preparations of supernatant fluids and protozoa 
Table 3. The incorporation of fractions from lysed $B$. megaterium by Epi. ecaudatum caudatum (ovine)

Protozoa ( 8800 in $2 \mathrm{ml}$ ) were incubated anaerobically for $3.5 \mathrm{~h}$ with varying concentrations of the soluble and pellet fractions prepared as described in the text after the lysis of $\mathrm{U}-{ }^{14} \mathrm{C}$-labelled $B$. megaterium with the lytic enzyme contained in the medium or in the protozoal broken-cell supernatant fluid. After incubation the incorporation of ${ }^{14} \mathrm{C}$ into washed protozoa was measured and the amount of material taken up calculated from the specific activity of the bacteria. Both uptakes at $10^{9} / \mathrm{ml}$ (in terms of intact bacteria from which the fraction was derived) and infinitely high concentration were determined from double reciprocal plots of uptake against substrate concentration. The uptakes are expressed in terms of protein and of intact bacteria from which the fraction was derived.

\begin{tabular}{|c|c|c|c|}
\hline & \multicolumn{2}{|c|}{$\begin{array}{l}\text { Bacteria from which fraction } \\
\text { derived } / \text { protozoon } / \mathrm{h}\end{array}$} & \multirow{2}{*}{$\begin{array}{c}\text { Protein at I mg } \\
\text { protein } / \mathrm{ml} \\
(\mathrm{ng} / \text { protozoon } / \mathrm{h})\end{array}$} \\
\hline & At infinite concn & at $10^{9} / \mathrm{ml}$ & \\
\hline \multicolumn{4}{|l|}{ Enzyme in medium } \\
\hline Soluble fraction & I35 & 126 & 0.087 \\
\hline Pellet fraction & 218 & 212 & 0.093 \\
\hline \multicolumn{4}{|c|}{$\begin{array}{l}\text { Enzyme in broken-cell } \\
\text { supernatant fluid }\end{array}$} \\
\hline Soluble fraction & 89 & 87 & 0.106 \\
\hline Pellet fraction & 465 & 454 & 0.177 \\
\hline
\end{tabular}

\section{Table 4. Products of the metabolism of bacterial amino acids by} Epi. ecaudatum caudatum (ovine)

Protozoa were incubated in Conway units (Conway, 1947) under $\mathrm{N}_{2}$ for $2 \mathrm{~h}$ in the presence of B. megaterium uniformly labelled with ${ }^{14} \mathrm{C}$ or labelled with a single ${ }^{14} \mathrm{C}$-amino acid (Coleman, 1967). Products were measured in the medium. ${ }^{14} \mathrm{CO}_{2}$ was measured after the addition of $\mathrm{HCl}$ by the method of Coleman (1956). Volatile acid ${ }^{14} \mathrm{C}$ was retained on a planchette in the presence of alkali but lost in the presence of acid. Non-volatile ${ }^{14} \mathrm{C}$-material was that which was retained on the planchette in the presence of acid.

${ }^{14} \mathrm{C}^{*}$ recovered in:

$\begin{array}{lccc}\text { Bacterial amino acid } & \text { Volatile acid } & \mathrm{CO}_{2} & \begin{array}{c}\text { Non-volatile } \\ \text { material }\end{array} \\ {\left[\mathrm{U}-{ }^{14} \text { C]ala }\right.} & 44 & \mathrm{I} 10 & 550 \\ {\left[\mathrm{U}-{ }^{14} \text { C]glu }\right.} & \mathrm{I3} & 100 & 390 \\ {\left[\mathrm{I}-{ }^{14} \mathrm{C}\right] \mathrm{glu}} & 0 & 53 & 520 \\ {\left[\mathrm{U}-{ }^{14} \text { C]ile }\right.} & 95 & 70 & 220 \\ \text { U-14C-labelled } B . & 8 \mathrm{I} & \mathrm{I} 63 & 600 \\ \text { megaterium } & & & \end{array}$

* $\mathrm{Mol} / \mathrm{I} 00 \mathrm{~mol} \mathrm{C}$ incorporated into protozoa.

were made from the crude rumen contents of sheep with an A (no Epidinium) or B (Epidinium present) type population and the release of ${ }^{14} \mathrm{C}$ into the supernatant fluid measured on incubation for o to $2 \mathrm{~h}$ with a washed suspension of $\mathrm{U}_{-}^{14} \mathrm{C}$-labelled $B$. megaterium (approx. ${ }^{8} \mathrm{O}^{8}$ bacteria and $10^{4}$ c.p.m. $/ \mathrm{ml}$ ). The preparations were cell-free supernatant fluids obtained by centrifuging at $10000 \mathrm{~g}$ for $80 \mathrm{~min}$, and a washed protozoal suspension obtained by allowing the protozoa in the rumen contents to settle under gravity for $\mathrm{I} \mathrm{h}$ at $39{ }^{\circ} \mathrm{C}$ followed by repeated washing of the sediment in salt soln $\mathrm{D}$ on the centrifuge at $200 \mathrm{~g}$ for $30 \mathrm{~s}$. On incubation of the supernatant fluid $\left(0.5 \mathrm{ml}\right.$ in $0.7 \mathrm{ml}$ incubation mixture), ${ }^{14} \mathrm{C}$ was always liberated from the bacteria with fluids from both types of sheep, but there were marked quantitative differences between experiments. For example, in one experiment 8700 c.p.m. were released in the presence of A type fluid compared with 8400 c.p.m. with B type fluid 
and I I00 c.p.m. in the absence of either, whereas, less typically, in another experiment with the same animals 2 days later, the corresponding results were I3IO, 6900 and 230 c.p.m. Lytic and probably proteolytic activity was always present in rumen fluid and occasionally it was more marked in sheep containing Epidinium spp. The washed protozoal suspensions from both population types digested $B$. megaterium rapidly and there was no obvious difference between them.

\section{DISCUSSION}

The cellular nitrogen of Epidinium spp. can be increased by the engulfment of bacteria or the incorporation of amino acids (Coleman \& Laurie, 1974) or, as shown above, by the uptake of material from lysed $B$. megaterium. This source is unlikely to be available to the protozoa as $B$. megaterium and the other sensitive bacteria are not present in the culture media in vitro or in the rumen in vivo. The importance of this lytic enzyme to the Epidinium spp. is therefore unknown.

Any increase in cellular nitrogen would, however, be reversed in part by the release of nitrogenous material by the protozoa. This latter phenomenon has also been found in a number of other protozoa. Entodinium caudatum in washed suspension after isolation from the rumen lost $1 \%$ of its cellular nitrogen/h (Abou Akkada \& Howard, 1962) but the mechanism is not known; it did not appear to be the result of cell lysis. Dickie \& Liener (1962) reported that appreciable amounts of nitrogenous material (over $2 \mathrm{mg} \mathrm{N} / \mathrm{ml}$ ), including a proteolytic enzyme, were released from the free-living protozoon Tetrahymena pyriformis during growth. Müller (1972) found that certain hydrolytic enzymes were released from washed suspensions of this protozoon more rapidly than general cell protein and were derived from a special population of lysosomes. Although a similar mechanism may be operative in the present studies, it is considered more likely that, because hexokinase was also released and because the specific activities of the enzymes are the same in the cell and the medium, some of the cell cytoplasm, possibly after modification in some way, is released into the medium without general cell lysis. It is not known why other rumen protozoa examined release protein but not lytic enzyme, although they contain it.

We thank Dr P. Kemp for inserting permanent rumen cannulae into the sheep, and members of the Sub-Department of Chemical Microbiology, Biochemistry Department, University of Cambridge, for helpful advice and criticism.

\section{REFERENCES}

Abou Akkada, A. R. \& Howard, B. H. (1962). The biochemistry of rumen protozoa. 5. The nitrogen metabolism of entodinium. Biochemical Journal 82, 31 3-320.

Coleman, G.S. (1956). The dissimilation of amino acids by Rhodospirillum rubrum. Journal of General Microbiology 15, 248-256.

Coleman, G. S. (1958). Maintenance of oligotrich protozoa from the sheep rumen in vitro. Nature, London I82, I I 04-I 105.

Coleman, G. S. (1960). The cultivation of sheep rumen oligotrich protozoa in vitro. Journal of General Microbiology 22, 555-563.

Coleman, G. S. (1964). The metabolism of Escherichia coli and other bacteria by Entodinium caudatum. Journal of General Microbiology 37, 209-223.

Colfman, G. S. (1967). The metabolism of the amino acids of Escherichia coli and other bacteria by the rumen ciliate Entodinium caudatum. Journal of General Microbiology 47, 449-464.

Coleman, G. S. (1969). The metabolism of starch, maltose, glucose and some other sugars by the rumen ciliate Entodinium caudatum. Journal of General Microbiology 57, 303-332. 
Coleman, G. S. (1972). The metabolism of starch, glucose, amino acids, purines, pyrimidines and bacteria by the rumen ciliate Entodinium simplex. Journal of General Microbiology 71, 117-131.

Coleman, G. S. (1973). The metabolism of bacteria and amino acids by three species of epidinia isolated from the rumen and cultured in vitro. Journal of General Microbiology $\mathbf{7 7}$, viii.

Coleman, G. S., Davies, J. I. \& CASH, M. A. (I972). The cultivation of the rumen ciliates Epidinium ecaudatum caudatum and Polyplastron multivesiculatum in vitro. Journal of General Microbiology 73, 509-521.

Coleman, G. S. \& Hall, F. J. (1974). The metabolism of Epidinium ecaudatum caudatum and Entodinium caudatum as shown by autoradiography in the electron microscope. Journal of General Microbiology $85,265-273$.

Coleman, G. S. \& LAURIE, J. I. (1974). The metabolism of starch, glucose, amino acids, purines, pyrimidines and bacteria by three Epidinium spp. isolated from the rumen. Journal of General Microbiology 85, 244-256.

Conway, E. J. (1947). Microdiffusion analysis and volumetric error. London: Crosby Lockwood and Son.

DICKIE, N. \& LIENER, I. E. (1962). A study of the proteolytic enzyme system of Tetrahymena pyriformis W. Purification and partial characterization of the constituent proteinases. Biochimica et biophysica acta 64, 4I-5I.

Lowry, O. M., Rosebrough, N. J., Farr, A. L. \& Randall, R. J. (1951). Protein measurement with the Folin phenol reagent. Journal of Biological Chemistry 193, 265-275.

MülLER, M. (1972). Secretion of acid hydrolases and its intracellular source in Tetrahymena pyriformis. Journal of Cell Biology 52, 478-487.

SomoGYI, M. (1945). Determination of blood sugar. Journal of Biological Chemistry 160, 69-73. 